MONIKA INKÓW

\title{
Formalization of operational management and its impact on the innovativeness of IT companies from Lubuskie Voivodeship
}

Monika Inków, M.A., University of Zielona Góra,

Faculty of Economics and Management,

Poland, ORCID: 0000-0002-3179-9404.

\section{Introduction}

It is nothing new that in the current changing environment innovation is a chance for survival and development of organizations. Many researchers indicate that successfully implemented innovations are a source of competitive advantage for an organization. There are also many publications on the problem of innovation and the factors that affect and determine it (Blommerde and Lynch 2016), while only few of these publications deal with the relationship between formalization and innovation in organizations (Miller 2008).

Formalization at the general level refers to the application of clear rules, procedures, and behaviors (Sivadas and Dwyer, 2000; Vlaar et al., 2006). In the literature on organization management, formalization is defined as a key attribute of the bureaucratic form of organization, and the research on the structure of formal organizations goes back to the very beginnings of the organization theory (Sine et al. 2006, Miller 2008). It is also worth mentioning that earlier studies perceived formalization as a defining component of 
organizational structure, which was defined by Mintzberg (1979, pp. 9-10) as "the sum of the ways in which an organization divides its work into separate tasks and achieves coordination between them". In his work Mintzberg (1979, pp. 9-10) distinguished between the formal structure, defining it as "documented, official relations between members of the organization", and the informal structure, which he defined as "unofficial relations in the working group". It is also worth adding that some authors believe that formalization is so closely related to organizations that the concept of organization and formalization can even be seen as one (Britan and Cohen 1980; Pugh et al. 1963; Scott 2003; Sine et al. 2006). In the past, "formality" was the main criterion distinguishing between formal organizations and other types of social structures; now, however, definitions no longer emphasize the formality of an organization because this formality has become epiphenomenal (Stinchcombe 2001).

Formalization as one of the key features of an organization has been alternately appreciated and condemned in recent years. As Abdallah and Langley (2014) note, formalization helps organizations deal with ambiguities when assessing strategic orientations. Formalization also helps to make the ongoing projects clearer and supports all consideration within the company (Sivadas and Dwyer 2000). In this approach, it can be said that formalization explains organizational processes and also acts as an integration tool (Song et al. 2011; Ketokivi and Castaner 2004; Frechet and Goy, 2017). It is worth mentioning that, in line with this argument, some researchers concluded that business plans increased both the efficiency and the possibility of survival of new ventures (Burk et al. 2010, Delmar and Shane 2003). On the other hand, Song et al. (2011) emphasized in their work that the number of new product development projects decreased with the growth of strategic planning, pointing to a negative relationship between strategy formalization and innovation.

Although Dibrell et al. (2014) found a direct, positive effect of formal strategic planning on the innovativeness of an organization in their research, like Mintzberg (1994) they also emphasized the potential negative impact of formalization on innovation.

When analyzing source literature, we can also notice that the number of studies both on innovation and on its determinants is significant, whereas the number of publications on the impact of formalization on organizational innovation is not so high, though it is still growing. Additionally, when analyzing the literature on formalization, we can see that so far, researchers have not come to a consensus regarding its impact either on organizations' results or on their innovation; therefore, the assumption of the presented work is to fill this gap to some 
extent. The aim of this article is to present the preliminary results of a broader research project on the relationship between the formalization of operational management and the innovation of IT organizations in Lubuskie Voivodeship.

\section{Formalization and innovation}

In the body of literature we can find examples of various tools recommended by various authors increasing the probability of success by innovations. However, as some researchers note, the role of these tools in the success of innovation has been called into question. It is related to the influence of formalization on organizational results, including innovation (Sivadas and Dwyer, 2000; Vlaar et al., 2006). It is worth mentioning that in recent years, researchers have focused their efforts on determining whether formalization improves or deteriorates organizational performance, including innovation (Frechet and Goy, 2017)

In the analysis of the impact of formalization on innovation organizations with a low level of formalization are referred to as organic organizational structures, while highly formalized organizations are called mechanistic organizational structures (Dedahanov et al. 2017). Organizations with an organic structure tend to increase the initiation of innovation (Duncan 1976). It is not assumed, however, that organic organizations trigger innovation, but rather that their organizational climate recognizes the need for innovation and provides more opportunities for innovation and supports stronger efforts for innovation (Cabello-Medina et al. 2013).

It is also worth mentioning that less formal structures give employees greater freedom in terms of their roles and decision making, which positively affects their creativity and innovation (Amabile et al. 1996, Cabello-Medina et al. 2013). A lower level of formalization also favors innovative behaviors, such as proposing new ways of achieving goals, searching for new technologies, and finally, research and securing resources necessary to implement new ideas, while a higher level of formalization generally makes these behaviors difficult (Yuan and Woodman 2010, Dedahanov et al. al. 2017).

In general, in the literature researchers show that formalization primarily prevents the generation of ideas, as low flexibility limits creativity (Troy et al. 2001). Organizations that are highly formalized, apart from creativity, also inhibit spontaneity and willingness to take risks and experiment among employees (Bidault and Cummings 1994; Menguc and Auch 2010; García-Granero et al. 2014).

As noted by Benner and Tusham (2003), formalization does not allow for deviations from the established rules, which results in the formation of highly 
inflexible structures. In organizations with a formalized structure, it is the management that usually imposes a certain work routine to which employees have to adapt. They are not left to choose how to perform tasks; what is more, the rules limit the possibilities of interaction and communication between employees in the organization. Lack of effective communication between employees limits the exchange of ideas between them and the generation of knowledge (Perthusa-Ortega et al. 2010; Agrawal 1993). Limiting the generation and flow of knowledge in the organization, in turn, reduces the possibility of experimenting and obtaining exploratory results (Brenner and Tusham 2003). It is worth adding that employees who follow the rules and procedures prevailing in the organization tend to solve problems with the use of routine solutions and tools, which has a negative impact on the generation of new ideas in the organization, especially when employees are afraid of being criticized for departing from the established principles of their position (RuizMoreno et al. 2013). Sopińska and Dziurski (2018) note, however, that the lack of formalization of cooperation makes it possible to shorten the innovation process.

It should be noted, however, that some researchers believe that innovative organizations with formalized mechanistic structures would be better prepared to create radical innovations, because such innovations require a structure with clearly defined reporting relationships in order to be able to ensure, above all, discipline, but also creativity. In addition, some kind of standardization of activities during the development of new products may even play a key role, providing a common language and framework to coordinate new product development tasks performed in different parts of the organization (Hage 1980; Jelinek and Schoonhoven 1993; Engwall et al. 2005). Furthermore, some authors indicate that clearly defined procedures reduce uncertainty and facilitate more effective quality management and innovation (McAdam et al. 2019; EscrigTena et al. 2021). As Padzik-Wołos (2020) notes, formalization and organized processes allow the organization to proceed from the emergence of an idea to its implementation. It is also worth mentioning that according to some authors, formalization positively influences radical innovations but negatively influences incremental innovations (Cardinal 2001; Cabello-Medina et al. 2013).

\section{Description of the research}

The research used to obtain the results presented in the article was conducted using the method of individual interview with the use of a standardized 
questionnaire. The questionnaire consisted of closed questions. A fivepoint Likert scale was used for all questions, where a rating of 1 meant "I strongly disagree" and a rating of 5 meant "I strongly agree". The part of the questionnaire on the formalization of operational management in an organization was adapted from the study by Wilden et al. (2013) on the relationship between dynamic abilities and organizational performance. As part of the survey, the respondents were presented with 7 microtheses (table 1) and asked to rate how much they agreed with them in relation to their organization.

Table 1. Microtheses on the formalization of operational management

\begin{tabular}{|c|c|}
\hline Code & Microthesis \\
\hline FZ01 & $\begin{array}{l}\text { In the organization there is casual, informal control and high dependence on informal } \\
\text { relations and standards of cooperation when performing work }\end{array}$ \\
\hline FZ02 & $\begin{array}{l}\text { There is a strong emphasis in the organization on getting things done, even if it means } \\
\text { ignoring formal procedures }\end{array}$ \\
\hline FZ03 & $\begin{array}{l}\text { There is a strong emphasis in the organization on freely adapting to changing circum- } \\
\text { stances without too much concern about previous practices }\end{array}$ \\
\hline FZ04 & $\begin{array}{l}\text { The styles of action of managers in the organization range from very formal to very } \\
\text { informal }\end{array}$ \\
\hline FZ05 & The codes of ethics applied in the organization sometimes seem to be just a "cover" \\
\hline FZ06 & $\begin{array}{l}\text { There is a strong tendency in the organization for the requirements of a given situation } \\
\text { and the personality of an individual to determine appropriate behavior in the work- } \\
\text { place }\end{array}$ \\
\hline FZ07 & $\begin{array}{l}\text { Formal management systems in the organization are more intended to build relation- } \\
\text { ships with stakeholders than to increase efficiency }\end{array}$ \\
\hline
\end{tabular}

Source: own study based on Wilden et al. 2013

On the other hand, the level of innovation of IT-owned organizations was measured by the number of areas in which the enterprise worked on innovations, as well as the frequency of work on innovations in a given area. The areas of work on innovations, in turn, were determined on the basis of the classification of innovative activity proposed in the OSLO manual, so the respondents were asked about the frequency of work on product and service, marketing, process, and organizational innovations. 


\section{Research results and discussion}

In the last twenty years, the information technology market has been dynamically developing, mainly as a result of the constantly progressing processes of computerization and digitization of societies. The fast and rapidly progressing computerization and digitization have become the reason for the implementation of hundreds of thousands of IT projects around the world.

According to the data presented by the Central Statistical Office (2020), a great part of entities from the IT industry are entities that conduct service activities. Moreover, according to a study by the Central Statistical Office, IT companies play a special role in the implementation of innovative projects (GUS 2020). It is worth emphasizing that enterprises from the ICT sector, which also includes the IT industry, displayed greater innovation in 2017-2019 than enterprises from other sectors of the Polish economy. According to the data of the Central Statistical Office (2020), slightly more than $25 \%$ of entities from the ICT sector introduced innovations, while among other enterprises this percentage was only $15.5 \%$.

The discussed research on the relationship between formalization and innovation in companies from the IT industry is conducted as part of a broader study on the determinants of innovative maturity of IT organizations in Lubuskie Voivodeship.

Forty companies from the IT industry in Lubuskie Voivodeship were subject to the study. The respondents were members of the management staff or owners of the surveyed enterprises. The characteristics of the respondents (with respect to the size of the enterprise) are presented in table 2. Fourteen of the surveyed entities operate in the field of software production and sale, ten entities are mainly involved in the sale of software, computer hardware and peripherals, nine of the surveyed entities deal with consulting in the field of IT, and seven entities provide services for servicing computer hardware, peripherals and software.

Table 2. Characteristics of respondents

\begin{tabular}{l|l|c|c}
\hline $\begin{array}{l}\text { Enterprise } \\
\text { characteristics }\end{array}$ & Category description & $\begin{array}{c}\text { Number of } \\
\text { respondents }\end{array}$ & \% of respondents \\
\hline $\begin{array}{l}\text { Number of } \\
\text { employees in the } \\
\text { enterprise }\end{array}$ & $<10$ persons & 30 & $75 \%$ \\
\cline { 2 - 4 } & $10-49$ persons & 5 & $12.5 \%$ \\
\cline { 2 - 4 } & $50-249$ persons & 4 & $10 \%$ \\
\cline { 2 - 4 } & $>249$ persons & 1 & $2.5 \%$ \\
\hline
\end{tabular}


When analyzing the respondents' answers regarding their innovative activities, it turned out that $25 \%$ of the respondents, i.e., 8 micro-enterprises and 2 small enterprises, indicated that they had not carried out any work on innovations in the previous three years; $22.5 \%$ of the respondents, i.e., 7 micro-enterprises, 1 medium and 1 large enterprise indicated that they had conducted work on innovations only in one of the four areas mentioned; $15 \%$ of the respondents, i.e., 3 micro-enterprises and 1 medium-sized enterprise had conducted works in three areas; and as many as $27.5 \%$ of the respondents, i.e., 8 micro-enterprises, 2 small enterprises and 1 medium-sized company indicated that they had been working on innovation in all four areas.

Table 3. Results of the conducted innovative works

\begin{tabular}{l|c|c|c|c}
\hline $\begin{array}{l}\text { Type } \\
\text { of } \\
\text { innovation }\end{array}$ & $\begin{array}{c}\text { Work } \\
\text { com- } \\
\text { menced }\end{array}$ & $\begin{array}{c}\text { These solutions were } \\
\text { implemented on the } \\
\text { scale of the organization }\end{array}$ & $\begin{array}{c}\text { New solutions } \\
\text { have been imple- } \\
\text { mented on the } \\
\text { market scale }\end{array}$ & $\begin{array}{c}\text { New solutions } \\
\text { have been imple- } \\
\text { mented on the } \\
\text { global scale }\end{array}$ \\
\hline $\begin{array}{l}\text { Product and } \\
\text { service }\end{array}$ & 6 & 3 & 14 & 6 \\
\hline Marketing & 10 & 0 & 7 & 2 \\
\hline Process & 3 & 12 & 3 & 0 \\
\hline Organizational & 5 & 10 & 5 & 0 \\
\hline
\end{tabular}

To sum up, it can be noted that as many as $75 \%$ of the respondents conducted innovative activities in at least one of the indicated areas. While referring to the frequency of work on innovations in individual areas, the respondents were asked to rate this frequency on a five-point scale from 1 to 5 , where 1 meant very rarely, and 5 - very often. The highest frequency of undertaken works occurs in product and service innovations, which is not surprising, because this type of innovation is often indicated in source literature as an important factor in the competitiveness of enterprises (Wołoszyn, Ratajczak 2008). In addition, the respondents indicated that as part of product and service innovation, the companies implemented as many as 14 new solutions in the market and 6 in the world (table 3). Marketing innovations, on the other hand, have the lowest frequency of undertaken innovative works, with the average of respondents' scores of 2.07, but despite the low frequency of undertaken works, 
the respondents indicated that as part of marketing innovations they had introduced as many as 7 new solutions on the market scale and 2 on the world scale. In the case of organizational innovations, a large dispersion of responses can be observed, and the average of the responses obtained is 3.10. The situation is similar in the case of process innovations, where the average result is also about 3 . This indicates a moderate frequency of undertaking works on process and organizational innovations by IT organizations in Lubuskie Voivodeship, while the results of this work most often include the introduction of certain improvements within the organization.

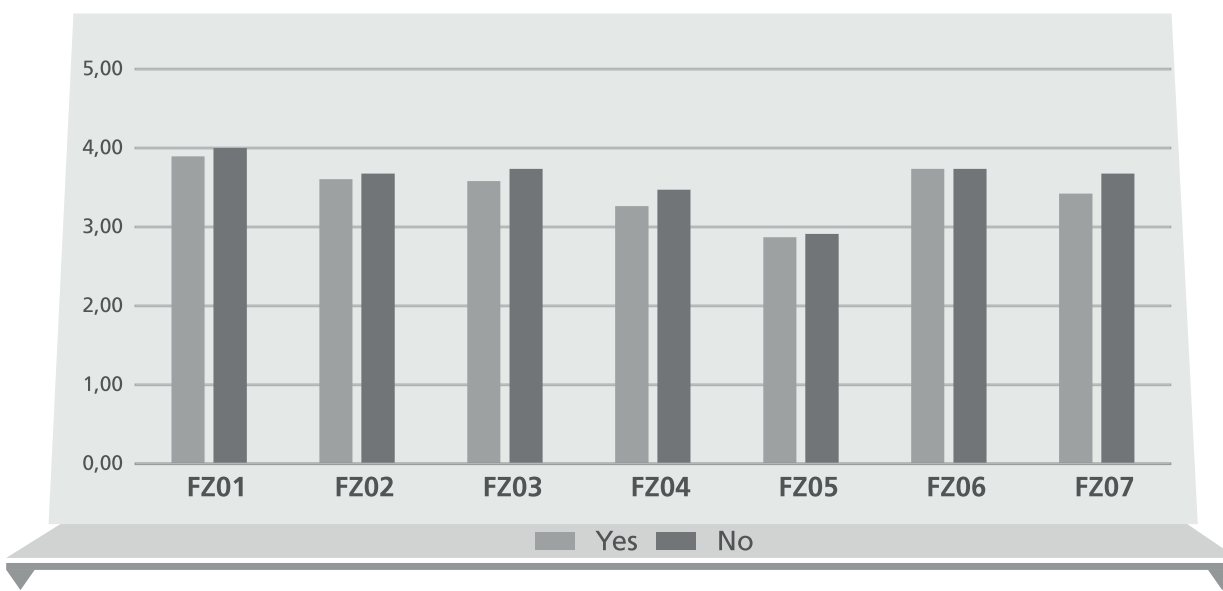

Figure 1. A list of the respondents' average scores for each of the microtheses presented for evaluation

Source: author's own research

\section{Legend}

FZ01-FZ07- average scores of individual microtheses (table 1)

No - assessments of microtheses made by respondents from organizations not undertaking work on innovations

Yes - assessments of microtheses made by respondents from organizations undertaking work on innovations

Turning to the analysis of the respondents' responses regarding the formalization of operational management in their organizations (fig. 1), it must be said that they are surprising, because paradoxically, enterprises which indicated that they had not undertaken any work on innovations had a lower degree of formalization. It is worth adding, however, that the average

Formalization of operational management and its impact on the innovativeness of IT companies from Lubuskie Voivodeship 
of the respondents' answers obtained for most of the microtheses presented to them for the evaluation ranged from 3.26 to 4.0 , which means a rather moderate degree of formalization of these organizations in general. It is also worth noting that according to previous studies, organizations characterized by a lower degree of formalization are those that are more innovative, because, as shown by researchers, a lower level of formalization of an organization positively influences its innovativeness (e.g. Cardinal 2001; Dedahanov 2017). However, it is worth noting that some researchers indicate that radical innovations are usually accompanied by a higher degree of formalization (Cardinal 2001; Cabello-Medina 2013; Dedahanov 2017), while in the case of the surveyed companies, solutions that are new on a global scale are also developed by organizations characterized by relatively low formalization. Thus, it can be stated that organizations without a properly developed formal framework are also able to develop solutions that are new on a global scale.

\section{Conclusion}

Currently, innovations are treated as a pillar of development, not only of organizations, but even of entire economies. It is successfully introduced innovations that often prove to be the decisive factor in the competitive advantage of an organization. However, in order for the organization to be able to successfully conduct work on innovations and implement them, it should create appropriate conditions for this, conditions allowing the flow of knowledge, stimulating creativity and creative thinking, as well as conditions that will create an appropriate framework allowing for the development of radical innovations. This is related to making a decision on the degree of formalization of the organization, a decision which is often very difficult to take, as evidenced by the ongoing debate among scientists on the relationship between formalization and innovation.

The conducted research has brought quite surprising results. It turned out that paradoxically, organizations which did not carry out innovative work at all were characterized by a lower degree of formalization. However, it is worth adding that the respondents' answers indicated a moderate degree of formalization of the surveyed organizations in general. In addition, the research results have shown that organizations characterized by a relatively low degree of formalization are also able to develop new innovations, not only on a national, but also on a global scale. 


\section{Summary}

In the changing environment, innovation gives organizations a chance to survive and develop. Researchers indicate that successfully implemented innovations are a source of competitive advantage for an organization. In source literature we can find examples of various tools recommended by the authors that increase the probability of innovation success. As some researchers note, the role of these tools has been questioned, which is related to the impact of formalization on innovation. In recent years, researchers have focused their efforts on determining whether formalization improves or deteriorates innovation; however, when analyzing the literature, it can be noticed that the number of studies on innovation and its determinants is significant, while the number of publications on the impact of formalization on organizational innovation is low. In addition, it can be noted that so far, researchers have not come to a consensus regarding the impact of formalization on either organizational results or innovation; therefore, the assumption of the presented work is to fill this gap to some extent. The aim of this article is to present the preliminary results of a broader research project on the relationship between the formalization of operational management and the innovation of IT organizations in Lubuskie Voivodeship.

Keywords: formalization, innovation, IT industry.

\section{Streszczenie}

W obecnym zmiennym otoczeniu szansą na przetrwanie organizacji oraz jej rozwój jest innowacyjność. Wielu badaczy wskazuje na to, że z sukcesem wdrażane innowacje są źródłem przewagi konkurencyjnej organizacji. W literaturze znaleźć można przykłady różnych narzędzi rekomendowanych przez różnych autorów zwiększających prawdopodobieństwo odniesienia sukcesu przez innowacje. Jak zauważa jednak część badaczy, rola tych narzędzi w sukcesie innowacji została postawiona pod znakiem zapytania. Związane jest to $\mathrm{z}$ wpływem jaki wywiera formalizacja na wyniki organizacyjne, w tym innowacyjność. Nadmienić warto, że w ostatnich latach badacze skupiali swoje wysiłki na ustaleniu, czy formalizacja 
poprawia, czy pogarsza wydajność organizacyjną, w tym również innowacyjność, jednakże analizując literaturę można zauważyć, że liczba opracowań dotyczących innowacyjności, i jej determinant jest znaczna, natomiast liczba publikacji dotyczących wpływu formalizacji na innowacyjność organizacji jest nieduża. Dodatkowo analizując literaturę dotycząca formalizacji zauważyć można, że jak do tej pory badacze nie doszli do konsensusu odnośnie jej wpływu zarówno na wyniki organizacji, jak i ich innowacyjność, w związku z tym założeniem prezentowanej pracy jest $w$ pewnym stopniu wypełnienie tej luki. Celem zaś niniejszego artykułu jest przedstawienie wstępnych wyników szerszych badań, które dotyczą związku pomiędzy formalizacją zarządzania operacyjnego a innowacyjnością organizacji z branży IT w województwie lubuskim.

\section{Słowa}

kluczowe: formalizacja, innowacyjność, branża IT.

JEL

classification: $\mathrm{O} 31, \mathrm{M} 10$.

\section{Literature}

Abdallah C., Langley A. (2014). The double edge of ambiguity in strategic planning. Journal of Management Studies, 51(2), pp. 235-264. DOI: https://doi.org/10.1111/joms.12002

Agarwal, S. (1993). Influence of formalization on role stress, organizational commitment, and work alienation of salespersons - a cross-national comparative study. Journal of International Business Studies. Vol. 24 no. 4, pp. $715-739$. DOI: $10.2307 / 155172$

Amabile, T., Conti, R., Coon, H., Lazenby, J., Herron M., (1996). Assessing the work environment for creativity. Academy of Management Journal. Vol 39, pp. 1154-1184. DOI:10.5465/256995

Amabile, T.M. (1996). Creativity In Context: Update To The Social Psychology Of Creativity (1st ed.). New York:Routledge. DOI: https://doi. org/10.4324/9780429501234

Benner, M., Tushman, M., (2003). Exploitation, exploration and process management: the productivity dilemma revisited. The Academy of Management Review. Vol. 28, pp. 238-256. DOI: http://dx.doi.org/10.5465/ amr.2003.9416096

Bidault, F., Cummings, T. (1994). Innovating through alliances: expectations and limitations. RED Management Vol. 24, pp. 33-45. DOI: http:// dx.doi.org/10.1111/j.1467-9310.1994.tb00845.x 
Blommerde T., Lynch P., (2016), A maturity matrix for assessing service innovation capability,http:// repository.wit.ie/3186/1/A\%20Maturity\%20 Matrix\%20for\%20Assessing\%20Service\%20Innovation \%20Capability.pdf [ 20.08.2021 access date].

Burke, A., Fraser, S., Greene, F. J. (2010). The multiple effects of business planning on new venture performance. Journal of Management Studies, Vol. 47(3), pp. 391-415. DOI: 10.1111/j.1467-6486.2009.00857.x

Cabello-Medina, C., Carmona-Lavado, A., Cuevas-Rodríguez, G., (2011). Organisation of R\&D departments as determinant of innovation: testing alternative explanations. Technology Analysis \& Strategic Management. Vol. 23, No. 4, pp. 383-400.

Cardinal, L.B. (2001). Technological innovation in the pharmaceutical industry: the use of organizational control in managing research and development. Organizational Science. Vol. 12 no. 1, pp. 19-36. DOI:10.1287/ orsc.12.1.19.10119

Dedahanov, A. T., Rhee, Ch., Yoon, J., (2017). Organizational structure and innovation performance. Is employee innovative behawior a missing link? Career Development International Vol. 22, No. 4. pp. 334-350. DOI 10.1108/CDI-12-2016-0234

Delmar, F., Shane, S. (2003). Does business planning facilitate the development of new ventures? Strategic Management Journal. Vol. 24(12), pp. 11651185. DOI: https://doi.org/10.1002/smj.349

Dibrell, C., Craig, J. B., Neubaum, D. O. (2014). Linking the formal strategic planning process, planning flexibility, and innovativeness to firm performance. Journal of Business Research, Vol. 67(9), pp. 2000-2007. DOI: 10.1016/j.jbusres.2013.10.011

Engwall, M., Kling, R., Werr, A., (2005). Models in action: how management models are interpreted in new product development. RED Management. Vol 35, pp. 427-439. DOI:10.1111/J.1467-9310.2005.00399.X

Escrig-Tena, A. B., Segarra-Cipr'es, M., García-Juan, B., (2021). Incremental and radical product innovation capabilities in a quality management context: Exploring the moderating effects of control mechanisms, International Journal of Production Economics, 232, pp. 1-10, DOI: https://doi. org/10.1016/j.ijpe.2020.107994

Fréchet, M., Goy, H., (2017). Does strategy formalization foster innovation? Evidence from a French sample of small to medium-sized enterprises.M@n@gement.Vol. 20(3),pp.266-286.

García-Granero, A., Vega-Jurado, J., Alegre-Vidal, J., (2014). Is R\&D Enough to Take Advantage From External Knowledge? Focusing on Coordination Mechanisms. Journal of Technology Management \& Innovation, Vol. 9, Iss. 2, pp.118-129.

GUS (2020). Społeczeństwo informacyjne w Polsce w 2020 r., Szczecin: GUS

Hage, J. (1980), Theories of organizations. NewYork:Wiley.

Jelinek, M., Schoonhoven, C., (1993), The innovation marathon. San Francisco CA: Jossey-Bass. 
Ketokivi, M.,Caastañer, X., (2004). Strategic planning as an integrative device. Administrative Science Quarterly. Vol. 49(3), pp. 337-365. DOI: https:/ / doi.org/10.2307/4131439

McAdam, R., Miller, K., McSorley, C., (2019). Towards a contingency theory perspective of quality management in enabling strategic alignment. International Journal of Production Economics,. 207, 195-209, DOI: 10.1016/j. ijpe.2016.07.003

Menguc, B., Auh, S., (2010). Development and return on execution of product innovation capabilities: the role of organizational structure. Industrial Marketing Management. Vol. 39, pp. 820-831. DOI: http://dx.doi. org/10.1016/j.indmarman.2009.08.004

Miller Ch. Z., (2008). Formalization and innovation: an ethnographic study of process formalization [Dissertation, Wayne State University].

Mintzberg, H. (1994), Rise and fall of strategic planning: Reconceiving the robes for planning, plans, planners (1st Ed.), New York, NY: Free Press.

Mintzberg, H., (1979). The Structuring of Organizations. Englewood Clifs: Prentice-Hall.

Oslo Manual (2018). Guidelines for Collecting, Reporting and Using Data on Innova-tion, Paris - Luxembourg: OECD Publishing-Eurostat

Padzik-Wołos, A., (2020), Employee-driven-innovation - contemporary context. Organizacja i Zarzadzanie, Vol. 82, pp.243-260. DOI: https://doi. org/10.21008/j.0239-9415.2020.082.15

Pertusa-Ortega, E. M., Zaragoza-Sáez, P., Claver-Cortés, E., (2010). Can formalization, complexity, and centralization influence knowledge performance? Journal of Business Research. Vol. 63 no. 3, pp. 310-320. DOI:10.1016/j.jbusres.2009.03.015

Pugh, D. S., Hickson, D. J., Hinings, C. R., Macdonald, K. M., Turner, C., Lupton, T., (1963). A conceptual scheme for organizational analysis. Administrative Science Quarterly, Vol. 8 pp. 289-315. DOI: https://doi. org/10.2307/2390971

Ruiz Moreno, A., Garc1'a-Morales, V. J., Llorens Montes, F. J., (2013). Determinants of proactive innovative behaviour in new services: empirical investigation of service versus manufacturing firms. The Service Industries Journal. Vol. 33, No. 11, pp. 977-1002. DOI: http:/ / dx.doi.org/10.1080/02 642069.2011.628987

Scott, W. R., (2003). Organizations: Rational, Natural and Open Systems. Upper Saddle River, New Jersey: Prentice Hall.

Sine, W. D., Mitsuhashi, H., Kirsch, D., (2006). Revisiting Burns and Stalker: Formal Structure and New Venture Performance in Emerging Economic Sectors. Academy of Management Journal. Vol. 49(1), pp. 121-132. DOI: https:/ / doi.org/10.5465/amj.2006.20785590

Sivadas, E., Dwyer, F. R., (2000). An examination of organizational factors influencing new product success in internal and alliance-based processes. Journal of Marketing, 64(1), pp. 31-49. DOI: https://doi.org/10.1509/ jmkg.64.1.31.17985 
Song M., Im S., Van Der Bij H., Song L. Z. (2011). Does strategic planning enhance or impede innovation and firm performance? Journal of Product Innovation Management, Vol. 28(4), pp.503-520, DOI: 10.1111/j.1540-5885.2011.00822.x

Sopińska A., Dziurski P., (2018), Strategie współpracy w otwartych innowacjach w Polsce, Organizacja i Kierowanie Iss. 2., pp. 147-158.

Stinchcombe A. L., (2001),.When Formality Works. Chicago: University of Chicago Press.

Troy, C., Szymanski, M., Varadarajan, P., (2001). Generating new product ideas: An initial investigation of the role of market information and organizational characteristics. Journal of the Academy of Marketing Science, Vol. 29(1), pp. 84-101. DOI:10.1177/0092070301291006

Vlaar, P., Van Den Bosch, F. A., Volberda, H. W., (2006). Coping with problems of understanding in interorganizational relationships: Using formalization as a means to make sense. Organization Studies, Vol.27(11), pp. 1617-1638.

Wilden, R., Gudergan, S. P., Nielsen, B. B., Lings, I., (2013). Dynamic Capabilities and Performance: Strategy, Structure and Environment. Long Range Planning, Vol. 46, Iss. 1-2, pp. 72-96. DOI: https://doi.org/10.1016/j. lrp.2012.12.001

Wołoszyn J., Ratajczak M., (2008). Innowacje produktowe w sektorze MSP w Polsce jako istotny czynnik konkurencyjności, in: Adamowicz M., (eds) Innowacyjność w sektorze agrobiznesu. Tom II. Rodzaje innowacji. Warszawa: Wydawnictwo SGGW

Yuan, F., Woodman, R.W., (2010). Innovative behaviour in the workplace: the role of performanceand image outcome expectations. Academy of Management Journal. Vol. 53 no. 2, pp. 323-342. 